\title{
The development of halal food industry in Bangka Belitung Island: an analytic network process
}

\author{
Suhel $^{1}$; Mukhlis ${ }^{2}$; Abdul Bashir ${ }^{3 *}$; Eka Fitriyanti ${ }^{4}$ \\ 1), 2), 3) Department of Development Economics, Faculty Economics, Universitas \\ Sriwijaya, Indonesia \\ ${ }^{4)}$ Department of Development Economics, Faculty Economics, Universitas Bangka \\ Belitung, Indonesia
}

*To whom correspondence should be addressed:abd.bashir@unsri.ac.id

\begin{tabular}{|l|l|l|l|l|}
\hline DOI: & Received: & Revised: & Accepted: & Published: \\
10.22437/ppd.v9i6.14434 & 18.08 .2021 & 18.02 .2022 & 23.02 .2022 & 28.02 .2022 \\
\hline
\end{tabular}

\begin{abstract}
This study analyzes the development of the halal food industry in Bangka Belitung Island. Development is measured by innovation strategy, product strategy, promotion strategy, pricing strategy, and collusion strategy. The data used are primary data obtained from in-depth interviews with five experts and practitioners with competent considerations in the field of the halal food industry - the analysis technique applying the Analytic Network Process. The findings indicated that the most superior aspects in the behavioral cluster are innovation strategy, product strategy, promotion strategy, price strategy, and collusion strategy. Meanwhile, the result from the benefit, cost, opportunity, risk (BOCR) cluster, the order of aspects that best describes the condition of the halal food industry in Bangka Belitung, is an opportunity, benefit, cost, risk. It is hoped that there will be a joint commitment from policy-makers in supporting and encouraging efforts to develop the halal food industry in Indonesia. It is expected that industry agents can further optimize industrial behavior, especially promotion and collaboration strategies.
\end{abstract}

Keywords: Analytic network process, Halal food, Halal industry

JEL Classification: L25, L52, O38

\section{INTRODUCTION}

The development of the halal concept, which is no longer limited to the food and beverage industry sector, has made the halal industry a potential new growth sector in the global economy (Ambali \& Bakar, 2014). This industry is growing 20 percent per year with an estimated value of US $\$ 560$ billion and an estimated total value of US\$2.3 trillion (Mubarok \& Imam, 2020). Recognizing the importance of the halal industry and its impact on the global economy, Food and Agriculture Organization (FAO) has also compiled guidelines for the use of the term halal for adoption by its member countries (Ager et al., 2015). Projections from the compound annual growth rate (CAGR), the halal industry will increase to $6.2 \%$ from 2018 to 2024 . The total funds spent by consumers of the halal industry will also reach USD 3.2 trillion in 2024 (Thomson 
Reuters, 2020). From these data, it can be seen that the halal industry has relatively good prospects.

Halal refers to everything permitted according to Islamic law (Abdelali \& Ngah, 2019). Consumption, one of the main pillars of Islamic economic activity, must adhere to the halal concept (Insani et al., 2019). The concept of halal, according to Islamic law which means it is not prohibited, while haram means prohibited or not justified according to Islamic law (Fauzi et al., 2020). Meanwhile, the term haram can be viewed from two aspects: (1) in terms of its limitations and essence, and (2) in terms of its form and nature (Fauzi et al., 2020). In addition, Islamic law also recommends that every food and drink be consumed to meet the Thayyib element, which is quality and does not endanger health (Nafis, 2019). However, some prohibited things can be allowed (Rohman, 2012). In addition, in some instances, halal products can become haram if consumed in excess (Yani \& Suryaningsih, 2019). The term halal in food or beverage products means something a Muslim consumes (Ambali \& Bakar, 2014).

The halal concept is related to the Maslahah concept as taking advantage and rejecting harm (danger) to maintain the goals of syara' (Islamic law) (Harun, 2009). Five things must be maintained in achieving maslahah: religion, soul, mind, lineage, and property. In relation to the halal-thayyib concept, taking care of everything consumed by the body, both food, and drink, is very important in maintaining the soul (maintaining the soul) and mind (hifdzul 'aql) as in the consumption of khamr (something intoxicating), which has been mentioned as haram in the Qur'an because of its intoxicating nature and can damage the mind. Ibn Qayyim in (Jauhar, 2009) says that even if someone is forced to drink it, they are still prohibited from drinking it.

Discussions related to halal industry studies have increased in recent years. Like the concept-based study on halal food conducted by Bohari et al. (2013) using SWOTICT analysis and Othman et al. (2009); Yusof \& Shutto (2014); Rahman et al. (2011); Alqudsi (2014); Yunos et al. (2014) used a review analysis and literature study. Other studies related to the halal food manufacturing industry were also conducted by (Yunus, Rashid, Ariffin, \& Rashid 2014). Yunus et al. (2014) analyzed halal awareness and buying interest, Muslim brands, and purchases. The study conducted by Ambali \& Bakar (2014) on public awareness and concern for halal food and products. Several researchers also analyzed the determinants of consumption of halal products, namely Briliana \& Mursito (2017), Asnawi et al. (2018), and perceptions of halal by consumers (Said et al. 2014; Rios et al. 2014; Rahim et al., 2016). Furthermore, the study discusses the halal industry development, such as the study that focuses on halal tourism (Battour \& Ismail, 2016; Olya \& Al-ansi, 2018).

The study by Secinaro \& Calandra (2020) findings that there are five study clusters, namely halal food and the role of certification, halal food and public awareness, production and quality of halal food, halal food in tourism management, and halal food and supply chain supplies (Alqudsi, 2014). The study conducted by Purwanto et al. (2020) discusses a sequential mixed methodology to examine the effects of the purchase intention of halal food on the perceptions of non-Muslim consumers in Indonesia, the quality of halal food, and knowledge regarding halal food safety (Mukhtar, 2012).

The growth of the halal industry also contributes positively to the Indonesian economy. The Islamic economy in Indonesia has been proven to contribute to a GDP of USD 3.8 billion annually (Indonesian Ministry of National Planning, 2019). The contribution to GDP is reflected in the consumption of Indonesian people and export 
and import activities for halal products (Fathoni, 2020). It was recorded that in 2017 the total consumption of halal products in Indonesia was USD 200 billion or more than $36 \%$ of total household consumption. This amount is also equivalent to $20 \%$ of Indonesia's GDP (Indonesian Ministry of National Planning, 2019). Consumption of halal products continues to grow with an average growth of 5.3\%. In 2025, it is estimated that the consumption level of Indonesian halal products will reach USD 330.5 billion (Fathoni, 2020). Bappenas stated that most of this large total consumption came from imported products (Fathoni, 2020). However, Indonesia can reduce the deficit in the trade balance if it increases production in the halal industrial sector (Indonesian Ministry of National Planning, 2019).

The Bangka Belitung Islands Province is one of the provinces that cares about the halalness of micro, small and medium enterprises (MSMEs) products. It is the first province in Indonesia to receive the 2017 Halal Award from the Institute for the Study of Food, Drugs, and Cosmetics, the Indonesian Ulama Council (Pemerintah Provinsi Kepulauan Bangka Belitung, 2017). The Indonesian Ulema Council (MUI) wants the Bangka Belitung Islands Province as a role model for the halal industry in Indonesia because Bangka Belitung offers many halal tourist destinations so that promotions will be profitable. For the Indonesian region and nation in advancing tourism and foreign tourist visits (Roanisca et al., 2020). In 2020, there are 1,155 halal certificates in Bangka Belitung Province. dominated by snack and food businesses, but restaurants and slaughterhouses are also (LPPOM MUI Babel, 2021).

Bangka Belitung Islands Province is trying several things to encourage MSMEs products to have high competitiveness, one of which is halal certification. First, about $89.4 \%$ of the people of Bangka Belitung are Muslim. Second, the characteristics of the Bangka Belitung area are dominated by the ocean, so it produces many marine biota products that can provide advantages and characteristics to support the prospects for the halal industry. It is undeniable that conventional marketing can no longer support halal industry business players in Bangka Belitung. Therefore, business actors must be aware of and understand technology, especially in marketing products (Majelis Ulama Indonesia, 2020).

The difference between this study and previous studies, such as that investigated by Soesilowati (2010), investigated the behavior of Muslim consumers and consumption of halal food in the context of business opportunities for halal products in the global market. Nurrachmi (2017) focuses on the existence of the halal food industry in developed and developing countries in increasing the presence of halal products in non-Muslim communities. Adiba (2019) investigates the effect of halal knowledge and Islamic religiosity on consumer behavior mediated by consumer attitudes. Al-Kwifi et al. (2019) investigated the brain response of Muslim consumers to Halal and non-Halal products using functional magnetic resonance imaging technology. Hanim et al. (2021) investigated the behavior of Muslims in making decisions to buy a halal product to optimize the halal industry. Djunaidi et al. (2021) analyzed the factors influencing consumer perceptions of buying halal products.

This study is pioneering for focused on analyzing the behavior of the halal industry of Bangka Belitung Island in Indonesia. The behavioral analysis to be studied is based on the theory of industrial organization. Baye (2010) stated that industrial behavior refers to how individual firms behave in the marketplace. This definition includes decisions related to pricing, advertising, investing in research and development activities, and several other behaviors. The novelty of this study to investigate the 
behavior halal food industry, in this case, can be seen from pricing strategy, promotion strategy, innovation strategy, product, and collusion strategy.

An in-depth study of the behavior of the halal food industry is still very much needed. A problem in this study is how the behavior of the halal industry in the Bangka Belitung Islands as a role model for the halal industry in Indonesia by using the Analytic Network Process (ANP) approach. Behavior is measured by innovation strategy, product strategy, promotion strategy, pricing strategy, and collusion strategy.

\section{METHODS}

Data

The data used are primary data obtained from in-depth interviews with experts and practitioners, who understand the problems discussed and are accompanied by filling out questionnaires. The selection of respondents in the study was carried out by considering the respondents' understanding of the problems in the halal industry in Bangka Belitung Island. The number of respondents in this study consisted of five experts and practitioners with competent considerations in the halal food industry. The requirements for valid respondents in the Analytic Network Process (ANP) do not need many. The important thing is that they master or are experts in their fields. Therefore, the respondents selected in this survey are experts/researchers of the halal industry and practitioners working in the halal industry.

\section{The ANP approach}

Analytic Network Process (ANP) is also a mathematical theory that can analyze the effect using assumptions to solve the problem. This method is used in the form of a solution by considering the adjustment of the complexity of the problem by analyzing the synthesis accompanied by a priority scale that produces the greatest priority effect. ANP can also explain the model of dependence factors and their feedback systematically. Decision-making in the ANP application is by considering and validating empirical experience. The network structure used is a benefit, opportunities, cost, and risk (BOCR). This method allows identifying, clarifying, and compiling all the factors that affect the output or the resulting decision (Saaty \& Vargas, 2006).

The ANP method is developing the Analytical Hierarchy Process (AHP) method. The ANP method can improve AHP's weaknesses in accommodating the interrelationships between criteria or alternatives (Saaty \& Vargas, 2006). There are two types of linkage in the ANP method: the relationship within a set of elements (inner dependence) and the relationship between different elements (outer dependence). The existence of this relationship causes the ANP method to be more complex than the AHP method. The advantage of ANP over other methods is its ability to assist decisionmakers in measuring a number of factors in a hierarchy or network. In addition, the concept is simpler. Therefore, the ANP method is more common and easier to apply in various qualitative studies.

According to Saaty \& Vargas (2006) and Kadoić et al. (2017), the ANP method is used to solve problems that depend on alternatives and existing criteria. ANP uses pairwise comparisons on project alternatives and criteria in its analysis technique. In the AHP network, there are levels of objectives, criteria, sub-criteria, and alternatives, where each level has an element. Meanwhile, the levels in AHP are called clusters in the ANP network, which can have criteria and alternatives in them, which are called nodes. 

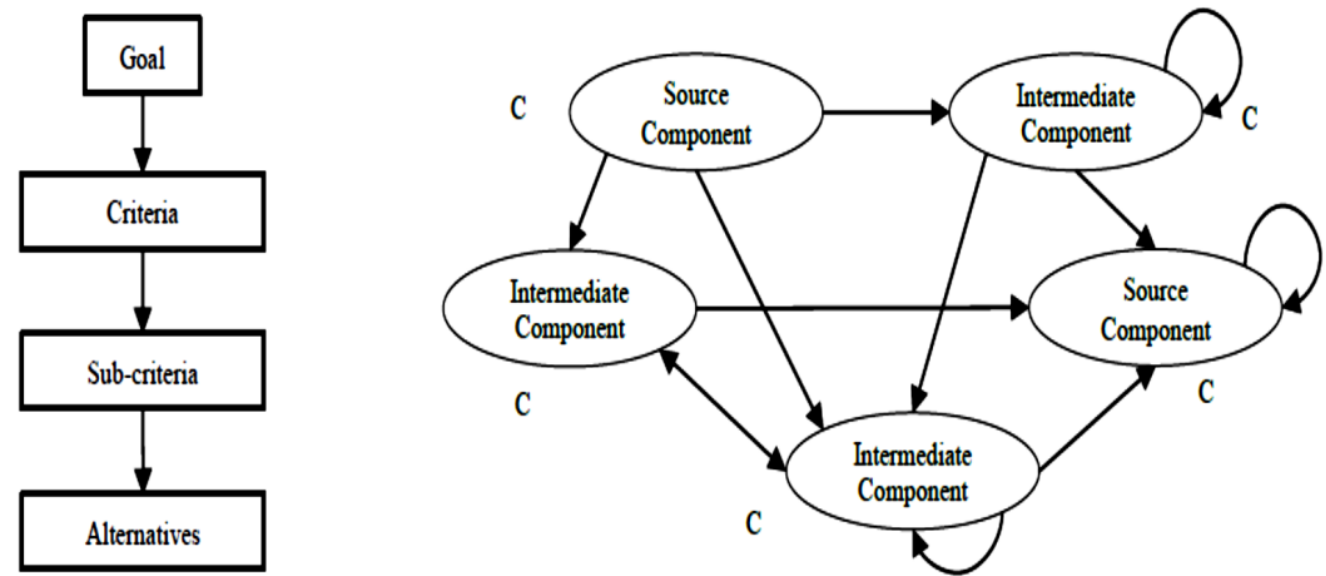

Figure 1. The structural difference between hierarchy and network

Source: Kadoić et al. (2017)

Figure 1 shows the analysis approach of structural differences between hierarchy and network. Hierarchy is a fundamental tool of the human mind in identifying the elements of a problem. Then these elements are grouped into homogeneous groups (components) and formulated in the form of different levels. There are no standard rules in the preparation of a hierarchical network. However, the arrangement of a hierarchical network must still be adapted to the decisions taken. In addition to using a hierarchical network, decision-making can also be done by creating a feedback network. This network more accurately describes a very complex research problem (Kadoić et al., 2017).

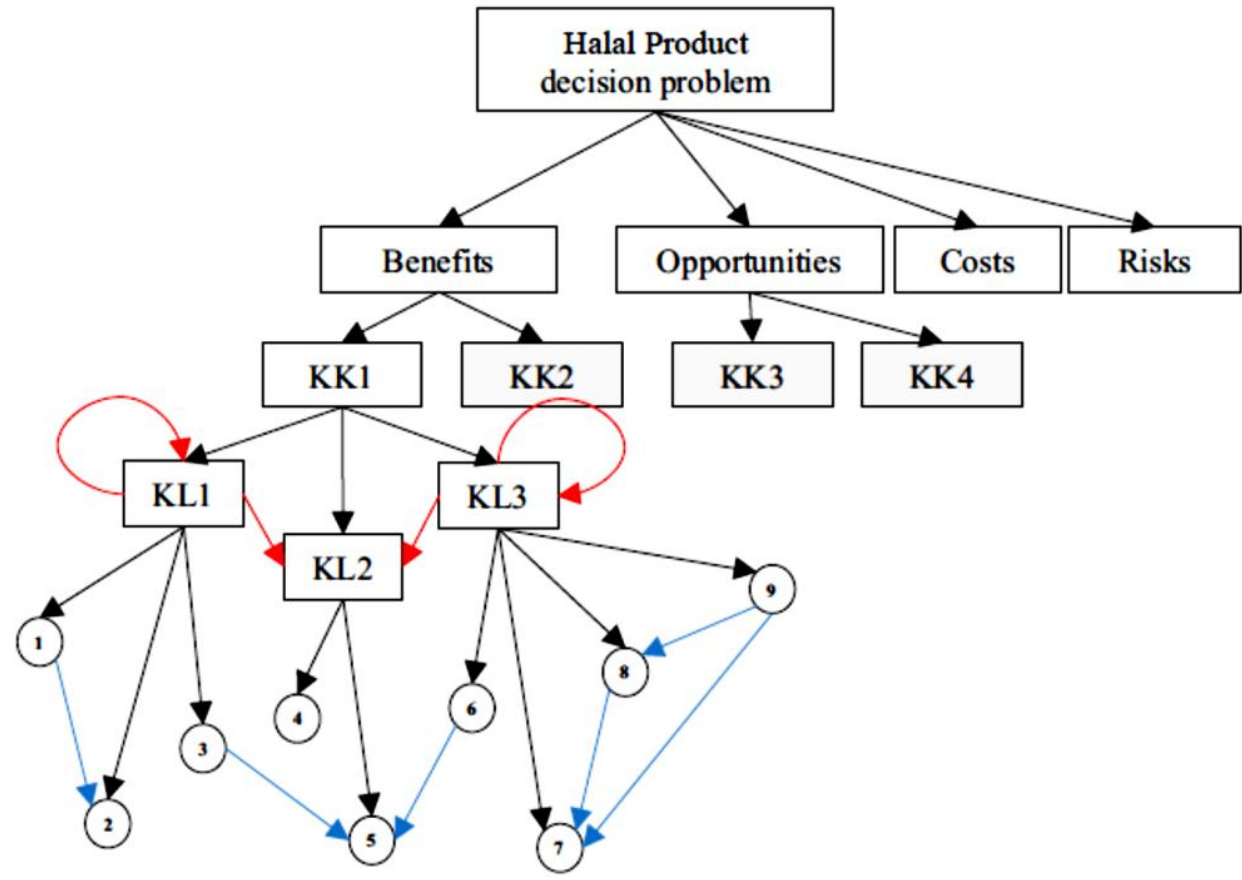

Figure 2. Structure of decision-making problem (evaluation of halal product)

Source: Kadoić et al. (2017)

Structuring the problem in decision making is a step that has been structured through benefits, control criteria, sub-criteria, clusters, and criteria. These elements are presented in Figure 2, ANP general decision-making problem. First, we have to decide 
which (good) network of problems to examine. For each merit selected, we must define a control criterion (and sub-criteria, if the decision-making problem is more complex), KK for each control criterion. We must identify the clusters and elements of the clusters of criteria. In addition, dependencies between criteria must be identified in the blue arc. Automatically, dependencies between clusters are created in the red arc (Kadoić et al., 2017).

The structuring process is highly dependent on the decision-making method to be applied. The selection of criteria and sub-criteria is important in applying the decisionmaking method. The criteria and influences/dependencies selected should realistically represent the problem area. Decision-makers should include all relevant criteria for a particular problem. Different agencies have similar or even the same decision-making problems, but the list of relevant criteria is not necessarily the same. Within the ANP, it is also important to identify all influences/dependencies between criteria. It is desirable to include experts relevant to the problem area and experts in decision-making using appropriate methods (Kadoić et al., 2017; Saaty \& Vargas, 2006).

\section{Research design stages}

This study is a qualitative-quantitative analysis that aims to capture a value or view represented by experts and practitioners of the halal industry about the behavior of the halal industry in Bangka Belitung. The analytical tool refers to a study by Kadoić et al. (2017; Saaty \& Vargas (2006) utilized is the ANP method and is processed using the "Super Decision" software.

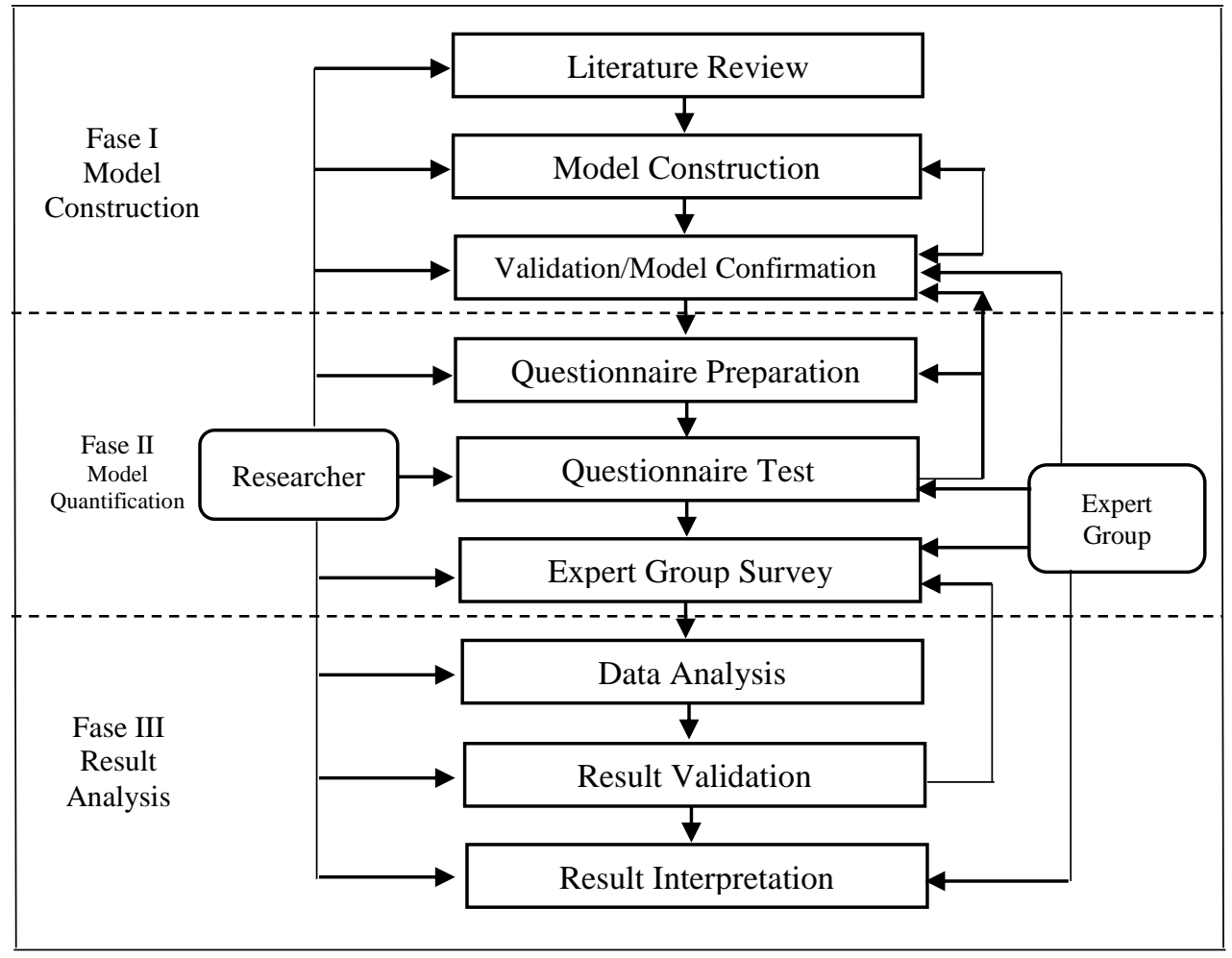

Figure 3. Research design stages

The study stages are divided into three phases. The first phase is constructing the ANP model based on a theoretical and empirical literature review and asking questions to experts and practitioners of the halal industry and through in-depth interviews to examine information more deeply to get to the real problem. The second phase is the 
quantification of the model using questions in the ANP questionnaire in the form of pairwise comparison between elements in the cluster to find out which of the two has the greater influence (more dominant) and how big the difference is through a numerical scale of 1-9.

\section{The ANP methods}

The data from the assessment is then collected and inputted through super decision software to be processed to produce outputs in the form of priorities and supermatrixes. The results of each respondent will be inputted into a separate ANP network (Ascarya, 2015). The third phase is synthesis and analysis based on geometric mean and rater agreement. Geometric mean to find out the results of individual assessments of the respondents and determine the results of opinions in one group, an assessment is carried out by calculating the geometric mean (Saaty \& Vargas, 2006). Questions in the form of comparison (Pairwise comparison) from the respondents will be combined to form a consensus. The geometric mean is a type of average calculation that shows a certain tendency or value which has the following formula (Ascarya, 2015):

$$
\left(\prod_{i}^{n}=1 a_{i}\right)^{1 / n}=\sqrt[n]{a_{1}} a_{2 \ldots} a_{n}
$$

Rater Agreement Rater agreement is a measure that shows the level of conformity (approval) of the respondents $\left(\mathrm{R}_{1}-\mathrm{R}_{\mathrm{n}}\right)$ to a problem in one cluster. Kendall's Coefficient of Concordance $(\mathrm{W} ; 0<\mathrm{W} \leq 1)$ is the tool used to measure rater agreement. $\mathrm{W}=1$ indicates a perfect match (Ascarya, 2015). To calculate Kendall's (W), the first is to rank each answer and add them up.

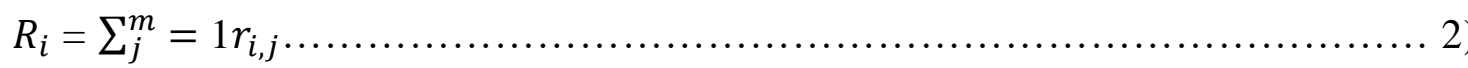

The average value of the total ranking is:

$R=\frac{1}{2} m(n+1)$.

The sum of the squares of deviation (SSD), is calculated by the formula:

$S S D=\sum_{i}^{n}=1\left(R_{i}-\bar{R}\right)^{2}$.

So that Kendall's (W) is obtained, namely:

$W=\frac{12 S}{m^{2}\left(n^{3}-n\right)}$

If the test value of $\mathrm{W}$ is $1(\mathrm{~W}=1)$, it can be concluded that the judgments or opinions of the respondents have a perfect match. Meanwhile, when the $\mathrm{W}$ value is 0 or is getting closer to 0 , it indicates a discrepancy between the respondents' answers or varied answers (Ascarya, 2015).

\section{RESULTS AND DISCUSSION}

\section{Result}

Industry behavior refers to decisions related to pricing, advertising, invest in research and development activities, and a number of other behaviors. The behavior usually refers to companies' behavior (actions or actions) in a market, their decisions, and how they are made. Well-known behavioral models include price-leadership, cartels, average cost pricing, and limit pricing. The behavior of one industry with another industry is different. One of them is caused by differences in the market 
structure of several industries. Behavior, in this case, can be seen from Price strategy, product strategy, promotion strategy, innovation strategy, and collusion strategy. The ANP-BOCR framework shows the behavior model of the halal food industry in Bangka Belitung in Figure 4.

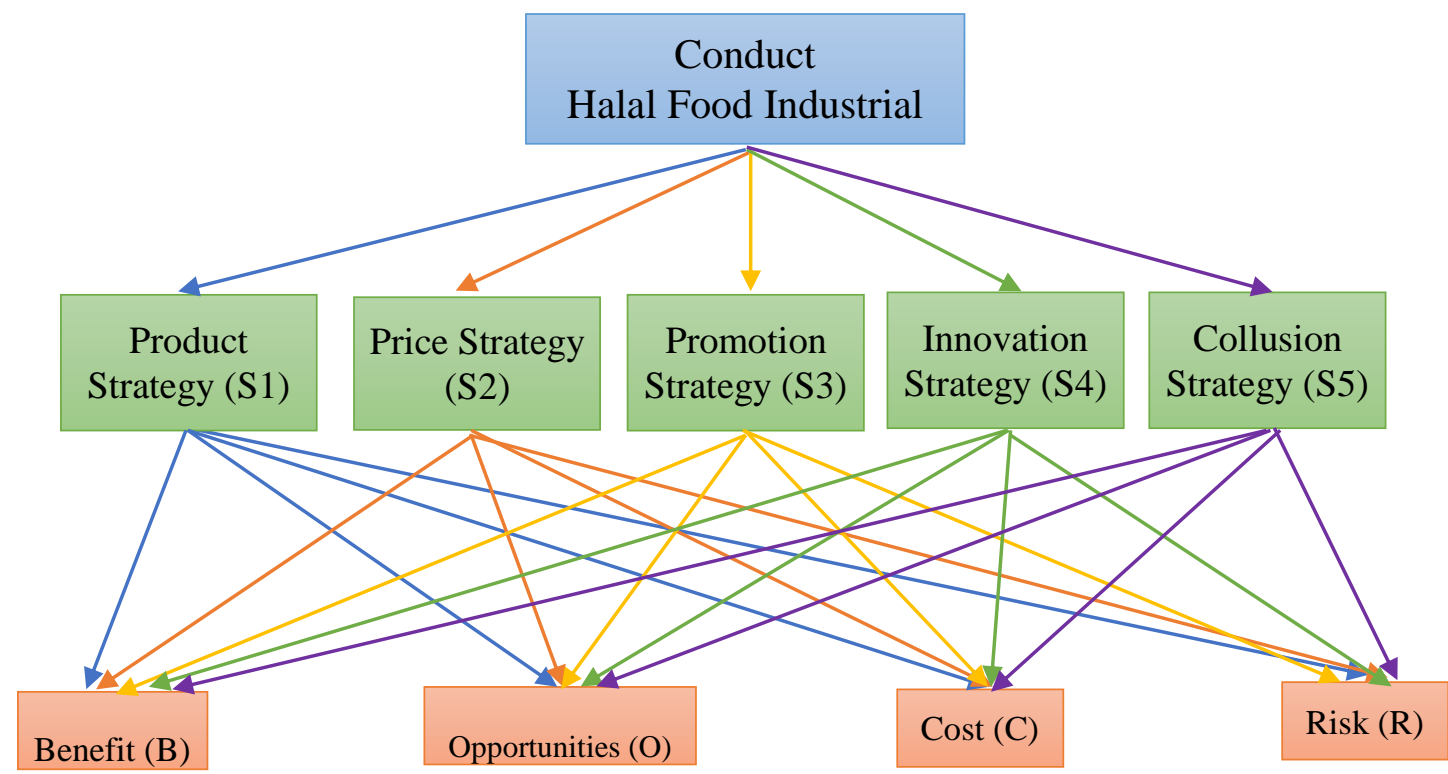

Figure 4. ANP-BOCR framework

The ANP network is formed where each element in one cluster is interconnected and interdependent with all elements in other clusters so as to form circular causation that resembles the interactive, integrative and evolutionary process orientation (IIE) of the ANP. Choudhury \& Hoque (2004) proposed the circular causation and continuity model.

Table 1. Concordance Kendall's coefficient of priority conduct

\begin{tabular}{lcccccc}
\hline Strategy & Wp & We & Conduct & SSD & Max SSD & W \\
\hline Price & 0.039 & 0.061 & 7 & 441 & 729 & \\
Innovation & 0.148 & 0.164 & 2 & 676 & 676 & \\
Collusion & 0.022 & 0.038 & 9 & 361 & 625 & \\
Product & 0.136 & 0.164 & 4 & 576 & 576 & \\
Promotion & 0.116 & 0.035 & 6 & 484 & 529 & \\
& & & 28 & 2538 & 3135 & 0.810 \\
\hline
\end{tabular}

Note: $W$ is Kendall's coefficient of concordance; $W p$ is Kendall's coefficient practitioner; and We is Kendall's expert coefficient

The results obtained show the statistical consensus of experts and practitioners. Table 3 shows that the expert results show that product and innovation strategies are two equally superior behaviors, with a fairly large rater agreement $(\mathrm{We}=0.825)$. As for practitioners, the behavior that most supports the success of the halal food industry in Bangka Belitung is the innovation strategy, while the product strategy follows, with a lower rater agreement value $(\mathrm{Wp}=0.802)$.

Overall, the innovation strategy is the leading behavior followed by the product strategy. The promotion strategy, then the price strategy, and the lowest in the collusion strategy, with a rater agreement level $(\mathrm{W}=0.810)$. 


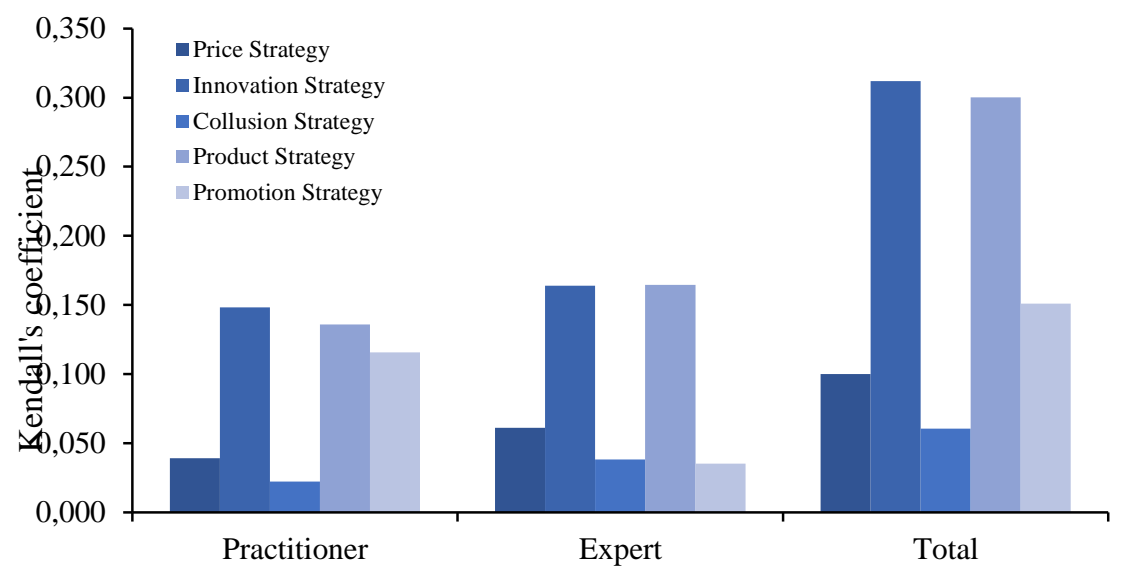

Figure 5. Priority conduct of halal food industry

Table 2. Result of Concordance Kendall's Coefficient of BOCR Priority

\begin{tabular}{lcccccc}
\hline Priority & Wp & We & BOCR & SSD & Max SSD & W \\
\hline Benefit & 0.107 & 0.139 & 5 & 361 & 529 & \\
Cost & 0.044 & 0.033 & 8 & 256 & 484 & \\
Opportunity & 0.212 & 0.190 & 1 & 529 & 441 & \\
Risk & 0.019 & 0.026 & 10 & 196 & 400 & \\
\hline & & & 24 & 1342 & 1854 & 0.724 \\
\hline
\end{tabular}

Note: $W$ is Kendall's coefficient of concordance; $W p$ is Kendall's coefficient practitioner; and We is Kendall's expert coefficient

In the BOCR cluster, as shown in Table 2, both experts and practitioners agree that the halal food industry in Bangka Belitung Belitung has a very high opportunity to become a role model for the halal food industry in Indonesia, with a high rater agreement of $(\mathrm{Wp}=0.722)$ and $(\mathrm{We}=0.718)$. After opportunity, overall respondents showed high benefits with minimal costs and risks, with a high rater agreement value of 0.724 .

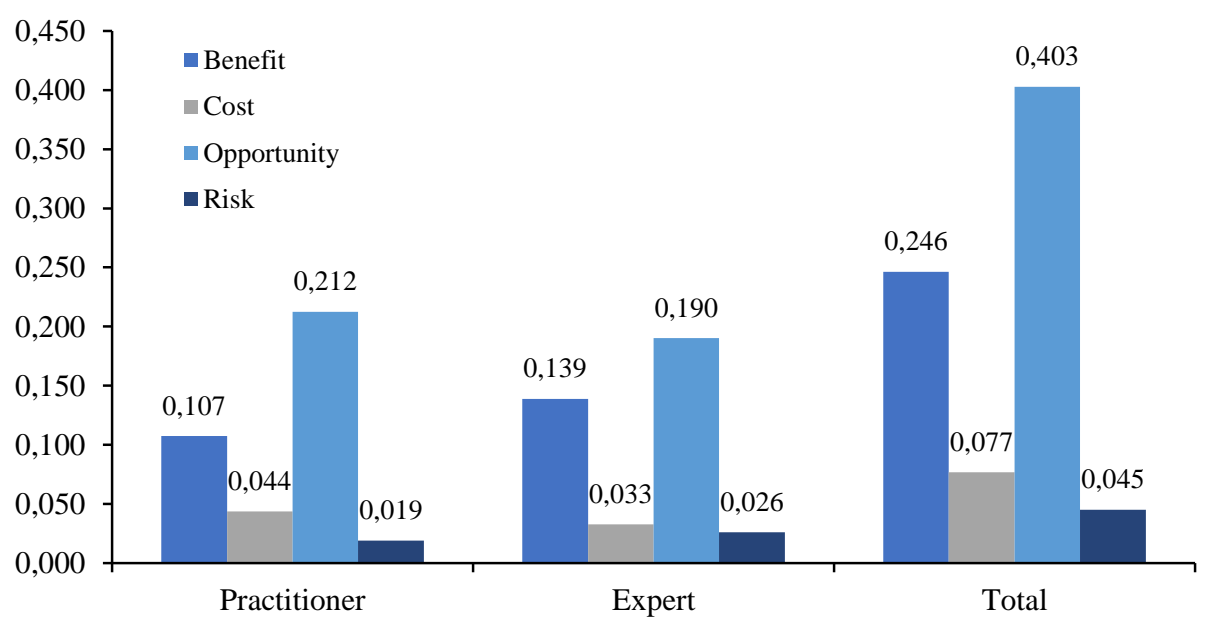

Figure 6. The BOCR priority of the halal food industry

\section{Discussion}

The findings of this study are relevant to the increasing number of Halal-certified food companies in Bangka Belitung. In 2017, the Institute for the Study of Food, Drugs, 
and Cosmetics of the Indonesian Ulema Council (LPPOM MUI) awarded the Halal Award, one of which was won by the Province of the Bangka Belitung Islands with the title of Best Halal Province. In 2016 there were 151 halal certificates issued by LPPOM MUI, a significant increase in 2020 as many as 1,155 halal certificates were issued, there was an increase of 66.30 percent during that period. Dominated by food and beverage products, there are also restaurants and abattoirs in Bangka Belitung Province (LPPOM MUI Babel, 2021).

Table 3. Number of food companies in Bangka Belitung halal certified

\begin{tabular}{lrrrrr}
\hline City/District & 2016 & 2017 & 2018 & 2019 & 2020 \\
\hline Pangkalpinang & 59 & 106 & 156 & 189 & 287 \\
Bangka & 5 & 41 & 87 & 112 & 146 \\
West Bangka & 5 & 11 & 23 & 45 & 69 \\
Central Bangka & 41 & 65 & 103 & 146 & 225 \\
South Bangka & 5 & 12 & 87 & 106 & 167 \\
Belitung & 24 & 38 & 62 & 93 & 151 \\
East Belitung & 12 & 33 & 56 & 87 & 110 \\
\hline
\end{tabular}

Source: Majelis Ulama Indonesia (2020)

Table 3 shows that food companies in Bangka Belitung that have halal certificates continue to increase every year. The number of food establishments in the table above is not evenly distributed, which dominates as the places most visited by tourists, in line with the research results conducted by Nawawi et al. (2019), which was conducted in Thailand with a non-Muslim majority. The study results indicate that Thailand's strength in the global halal industry scene is because the tourism industry is very crowded, which helps to improve the country's halal branding.

From the Network Process analysis on the behavioral cluster, the innovation strategy ranks first in describing the advantages of the halal food industry in Bangka Belitung Island. The innovation strategy provides great benefits for the halal food industry in Bangka Belitung, such as processed fish food that does not have waste because the waste is processed into products worth selling. Utilization of waste into salable value products is part of the product strategy aspect, namely creating unique and diverse product differentiation and diversification.

The next aspect is the promotion strategy which ranks third in the behavioral cluster. Promotional strategies in the halal food industry in Bangka Belitung still affect cost and risk. According to respondents, currently, the world's most sought-after promotion is digital promotion, but that is what is still lacking in the halal food industry in Bangka Belitung. Strategy Promotion is very closely related to cost and risk because when a promotion increases production costs, it will cause a risk, namely reduced profits. Meanwhile, the halal food industry in Bangka Belitung has not increased product prices due to high raw material and operational prices.

Price strategy ranks fourth in the behavioral cluster. Respondents agree that there is no suitable pricing strategy for the halal food industry in Bangka Belitung. The prices of halal food products in Bangka Belitung are still higher than similar products in other regions in Indonesia, even though it costs nothing to get the halal label. With the existing prices, Bangka Belitung can compete by choosing its market segmentation because the price given is by the quality of the product. Bangka Belitung has a wealth of quality seafood, so it greatly affects the taste of its halal food products.

The collusion strategy is the lowest ranking aspect in the behavior cluster of the halal food industry in Bangka Belitung. The aspect of collusion strategy can be a solution to existing problems if it functions optimally. According to Bohari et al. (2013) 
collusion is a strategy used by companies that avoid competition, both price and nonprice. In this case, firms in the market work together to reach mutual agreements regarding prices, levels of output produced, advertising activities, or budgeting for research and development.

The discourse of the Indonesian Ulama Council (MUI) wanting the Province of the Bangka Belitung Islands as a role model for the halal industry in Indonesia was supported by the geometric mean results in the BOCR cluster. According to respondents, the highest assessment of the halal food industry in Bangka Belitung, namely opportunity, was the highest value because Bangka Belitung is a tourism area and a Muslim-majority area.

The benefits aspect ranks second in describing the halal food industry in Bangka Belitung. The high benefits are in line with research conducted by Valeriani, Hidayati, \& Wulandari (2020), namely the large number of Muslim tourists who travel to the province of Bangka Belitung, the tendency of the community to uphold Islamic culture and values in customs in Bangka Belitung, local government support for MSME products to be halal certified. Furthermore, the analysis of cost and risk aspects which have a value below $10 \%$, is considered not to affect the halal food industry in Bangka Belitung.

\section{CONCLUSIONS AND RECOMMENDATIONS}

\section{Conclusions}

The conclusion of this research is a behavioral cluster. The most superior aspects are innovation strategy, product strategy, promotion strategy, pricing strategy, and collusion strategy. While in the BOCR cluster, the order of aspects that best describes the condition of the halal food industry in Bangka Belitung is an opportunity, benefit, cost, risk. The results of the ranking in the BOCR cluster, the opportunity, and benefits aspects are at the top, indicating that the behavior of the halal food industry in Bangka Belitung can be used as a role model in Indonesia. Based on Kendall's coefficient cluster behavior, the level of conformity or agreement between respondents shows Kendall's coefficient value (W), which is relatively large in expert respondents compared to practitioners. This shows that expert opinion has a greater degree of agreement. Thus, to set a behavioral strategy, expert opinion is more considered.

\section{Recommendations}

The recommendations in this study, among others (1) there will be a joint commitment from policy-makers in supporting and encouraging efforts to develop the halal food industry in Indonesia; (2) industry agents are expected to be able to optimize industrial behavior, especially promotion and collusion strategies; and (3) future research to be able to expand academic research studies related to halal food industry instruments with the number of subcategories in the network process analysis.

\section{ACKNOWLEDGMENT}

We would like to thank various parties who have helped so that this research can be completed properly. Special thanks go to the Department of Development Economics, Faculty of Economics, Sriwijaya University, and Bangka Belitung University for granting this study permission.

\section{REFERENCES}

Abdelali, B. Z., \& Ngah, B. B. (2019). Empirical Analysis of Mcdonald's Fast-Food in Malaysia Based on Halāl Food Regulations in Sūrah Al-Mā'idah. Asian Social 
Science, 15(7), 134-143.

Adiba, E. M. (2019). Consumer Purchasing Behavior of Halal Cosmetics: A Study on Generations X and Y. Journal of Islamic Monetary Economics and Finance, 5(1), 169-192. https://doi.org/10.21098/jimf.v5i1.1052.

Ager, S. N. S., Marliana Abdullah, F. M., Shahwahid, N. A. W., \& Saidpudin, W. (2015). War 11 An Analysis of the Definition of Halal: Shariah vs Statutes. World Academic and Research Congress 2015. Jakarta: YARSI University

Alqudsi, S. G. (2014). Awareness and Demand for 100\% Halal Supply Chain Meat Products. Procedia-Social and Behavioral Sciences, 130, 167-178. https://doi.org/10.1016/j.sbspro.2014.04.021

Al-Kwifi, O. S., Abu Farha, A., \& Ahmed, Z. U. (2019). Dynamics of Muslim consumers' behavior toward Halal products: Exploration study using fMRI technology. International Journal of Emerging Markets, 14(4), 689-708. https://doi.org/10.1108/IJOEM-11-2017-0486

Ambali, A. R., \& Bakar, A. N. (2014). People's Awareness on Halal Foods and Products: Potential Issues for Policy-makers. Procedia-Social and Behavioral Sciences, 121, 3-25. https://doi.org/10.1016/j.sbspro.2014.01.1104

Ascarya, A. (2015). Determining the Real Causes of Financial Crisis in Islamic Economic Perspective: ANP Approach. Tazkia Islamic Finance and Business Review, 9(2), 271318.

Asnawi, N., Sukoco, B. M., \& Fanani, M. A. (2018). Halal Products Consumption in International Chain Restaurants Among Global Moslem Consumers. International Journal of Emerging Markets. 13(5), 1273-1290. https://doi.org/10.1108/IJoEM11-2017-0495

Battour, M., \& Ismail, M. N. (2016). Halal Tourism: Concepts, Practises, Challenges and Future. Tourism Management Perspectives, 19(Part-B), 150-154. https://doi.org/10.1016/j.tmp.2015.12.008

Baye, M. R. (2010). Managerial economics and business strategy. The Mc-Graw Hill.

Bohari, A. M., Hin, C. W., \& Fuad, N. (2013). The Competitiveness of Halal Food Industry in Malaysia: A SWOT-ICT Analysis. Geografia-Malaysian Journal of Society and Space, 9(1), 1-9.

Briliana, V., \& Mursito, N. (2017). Exploring Antecedents and Consequences of Indonesian Muslim Youths' Attitude towards Halal Cosmetic Products: A Case Study in Jakarta. Asia Pacific Management Review, 22(4), 176-184. https://doi.org/10.1016/j.apmrv.2017.07.012

Choudhury, M. A., \& Hoque, M. Z. (2004). An Advanced Exposition of Islamic Economics and Finance. New York: Edwin Mellen Press.

Djunaidi, M., Oktavia, C. B. A., Fitriadi, R., \& Setiawan, E. (2021). Perception and Consumer Behavior of Halal Product Toward Purchase Decision in Indonesia. Jurnal Teknik Industri, $\quad 22(2), \quad$ 171-184. https://doi.org/10.22219/JTIUMM.Vol22.No2.171-184

Fathoni, M. A. (2020). Potret Industri Halal Indonesia: Peluang dan Tantangan. Jurnal Ilmiah Ekonomi Islam, 6(3), 428-435. https://doi.org/10.29040/jiei.v6i3.1146

Fauzi, M., Azizah, A. N., \& Nurfauziyah, L. (2020). The Concept of Ifta 'in Establishing Halal Law (Study of Usul fiqh on Legal Determination Methods). Journal of Digital Marketing and Halal Industry, 1(1), 83-92. https://doi.org/10.21580/jdmhi.2019.1.1.4776

Hanim, A., Dewi, I. R., \& Istiyani, N. (2021). Muslim Consumer Behavior Towards Halal Industry 4.0: Attitudes and Perceived Risk. International Conference on Management, Business, and Technology, 120-125. 
Harun, H. (2009). Pemikiran Najmudin At-Thufi Tentang Konsep Maslahah Sebagai Teori Istinbath Hukum Islam. Jurnal Ishraqi, 5(1), 21-34

Indonesian Ministry of National Planning. (2019). Indonesia Islamic Economic Masterplan 2019-2024. Indonesian Ministry of National Development Planning.

Insani, T. D., Al-Faizin, A. W., \& Ryandono, M. N. H. (2019). The Impact of Halal At Thayyib and Consumption Ethics Impact on Economic Growth: An Economic Tafsir Al-Baqarah: 168. Journal of Islamic Monetary Economics and Finance, 5(2), 459-474. https://doi.org/10.21098/jimf.v5i2.1071

Jauhar, A. A. H. (2009). Maqashid Syariah. Jakarta: Amzah

Kadoić, N., Ređep, N. B., \& Divjak, B. (2018). A New Method for Strategic Decisionmaking in Higher Education. Central European Journal of Operations Research, 26(3), 611-628. https://doi.org/10.1007/s10100-017-0497-4

LPPOM MUI Babel. (2018). Lulus Sertifikasi Halal, Produk Dijamin Aman. https://www.babelprov.go.id/

Mubarok, F., \& Imam, M. (2020). Halal Industry in Indonesia; Challenges and Opportunities. Journal of Digital Marketing and Halal Industry, 2(1), 55-64. http://dx.doi.org/10.21580/jdmhi.2020.2.1.5856

Majelis Ulama Indonesia. (2020). MUI Menjawab Berbagai Hal Tentang Halal. Jurnal Halal No. 144/2020, 144, 1-120.

Mukhtar, A. (2012). Intention to Choose Halal Products: The Role of Religiosity. Journal of Islamic Marketing, 3(2), 108-120. http://dx.doi.org/10.1108/17590831211232519

Nafis, M. C. (2019). The Concept of Halal and Thayyib and its Implementation in Indonesia. Journal of Halal Product and Research, 2(1), 1-5. http://dx.doi.org/10.20473/jhpr.vol.2-issue.1.1-5

Nawawi, M. S. A. M., Abu-Hussin, M. F., Faid, M. S., Pauzi, N., Man, S., \& Sabri, N. M. (2019). The emergence of halal food industry in non-Muslim countries: a case study of Thailand. Journal of Islamic Marketing.

Nurrachmi, R. (2017). The Global Development of Halal Food Industry: A Survey. Tazkia Islamic Finance and Business Review, 11(1), 41-56.

Olya, H. G. T., \& Al-ansi, A. (2018). Risk Assessment of Halal Products and Services: Implication for Tourism Industry. Tourism Management, 65, 279-291. https://doi.org/10.1016/j.tourman.2017.10.015

Othman, R., Ahmad, Z. A., \& Zailani, S. (2009). The Effect of Institutional Pressures in the Malaysian Halal Food Industry. International Business Management, 3(4), 80-84.

Pemerintah Provinsi Kepulauan Bangka Belitung. (2018). Informasi Laporan Penyelenggaraan Pemerintahan Daerah (Ilppd) Pemerintah Provinsi Kepulauan Bangka Belitung Tahun 2017. Pangkalpinang: Pemerintah Provinsi Kepulauan Bangka Belitung.

Purwanto, H., Fauzi, M., Wijayanti, R., Al Awwaly, K. U., \& Jayanto, I. (2020). Developing Model of Halal Food Purchase Intention among Indonesian NonMuslim Consumers: An Explanatory Sequential Mixed Methods Research. Systematic Reviews in Pharmacy, 11(10), 396-407.

Rahim S.A., Mohammad B., \& Rahman N.A.A. (2016) Influencing Factors on Halal Fourth-Party Logistics (4PL) in Malaysia. In: Ab. Manan S., Abd Rahman F., Sahri M. (eds) Contemporary Issues and Development in the Global Halal Industry. Singapore: Springer. https://doi.org/10.1007/978-981-10-1452-9_49

Rahman, A. H. A., Ahmad, W. I. W., Mohamad, M. Y., \& Ismail, Z. (2011). Knowledge on Halal Food Amongst Food Industry Entrepreneurs in Malaysia. 
Asian Social Science, 7(12), 216-221. http://dx.doi.org/10.5539/ass.v7n12p216

Roanisca, O., Yusnita, M., \& Mahardika, R. G. (2020). Pendampingan Usaha Mikro dan Masyarakat Desa Balunijuk dalam Mewujudkan Kampung Halal. Agrokreatif: Jurnal Ilmiah Pengabdian Kepada Masyarakat, 6(2), 173-180. https://doi.org/10.29244/agrokreatif.6.2.173-180

Rios, R. E., Riquelme, H. E., \& Abdelaziz, Y. (2014). Do Halal Certification Country of Origin and Brand Name Familiarity Matter? Asia Pacific Journal of Marketing and Logistics, 26(5), 665-686. https://doi.org/10.1108/APJML-03-2014-0046

Saaty, T. L., \& Vargas, L. G. (2006). Decision Making with the Analytic Network Process (Vol. 282). Springer.

Said, M., Hassan, F., Musa, R., \& Rahman, N. A. (2014). Assessing Consumers' Perception, Knowledge and Religiosity on Malaysia's Halal Food Products. Procedia-Social and Behavioral Sciences, 130, 120-128.

Secinaro, S., \& Calandra, D. (2020). Halal food: structured literature review and research agenda. British Food Journal, 123(1), 225-243. https://doi.org/10.1108/BFJ-03-2020-0234

Soesilowati, E. S. (2018). Business opportunities for Halal Products in the Global Market: Muslim Consumer Behaviour and Halal food Consumption. Journal of Indonesian Social Sciences and Humanities, 3(1), 151-160. https://doi.org/10.14203/jissh.v3i1.50.

Sholeh, A. N. (2018). Jaminan Halal pada Produk Obat: Kajian Fatwa MUI dan Penyerapannya dalam UU Jaminan Produk Halal. Journal of Islamic Law Studies, 1(1),70-87.

Thomson Reuters, D. S. (2020). State of the Global Islamic Economy Report 2018/19. $\begin{array}{llll}\text { Dubai International Financial } & \end{array}$ https://haladinar.io/hdn/doc/report2018.pdf

Valeriani, D., Hidayati, M. Y., \& Wulandari, A. (2020). Potential of Bangka Belitung tourism towards the world Halal tourism award through tourist perception with SWOT analysis. Journal of Critical Reviews, 7(6), 1093-1098.

Yani, M. T., \& Suryaningsih, S. A. (2019). Muslim Consumer Behavior and Halal Product Consumption. Al-Uqud: Journal of Islamic Economics, 3(2), 161-173. https://doi.org/10.26740/al-uqud.v3n2.p161-173.

Yunos, R. M., Mahmood, C. F. C., \& Mansor, N. H. A. (2014). Understanding Mechanisms to Promote Halal Industry-The Stakeholders' Views. Procedia Social and Behavioral Sciences, 130, 160-166. https://doi.org/10.1016/j.sbspro.2014.04.020

Yunus, N. S. N. M., Rashid, W. E. W., Ariffin, N. M., \& Rashid, N. M. (2014). Muslim's Purchase Intention towards Non-Muslim's Halal Packaged Food Manufacturer. Procedia - Social and Behavioral Sciences, 130, 145-154. https://doi.org/10.1016/j.sbspro.2014.04.018

Yusof, S. M., \& Shutto, N. (2014). The Development of Halal Food Market in Japan: An Exploratory Study. Procedia - Social and Behavioral Sciences, 121(September 2012), 253-261. https://doi.org/10.1016/j.sbspro.2014.01.1126

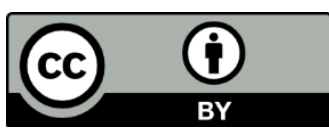

(C) 2022 by the authors. Licensee JPPD, Indonesia. This article is an open-access article distributed under the terms and conditions of the Creative Commons Attribution (CC BY) license (http://creativecommons.org/licenses/by/4.0/). 